\title{
ANALISIS KEBUTUHAN TAKSI GOGO DI KOTA KUPANG DENGAN TEKNIK STATED PREFERENCE
}

\author{
Febriany S. L. Lado ${ }^{1}$, Margareth E. Bolla ${ }^{2}$, \\ Prodi Teknik Sipil, Fakultas Sains dan Teknik, Universitas Nusa Cendana \\ 1,2 Dosen Prodi Teknik Sipil, Fakultas Sains dan Teknik, Universitas Nusa Cendana \\ Jl. Adi Sucipto Penfui, Kota Kupang, Nusa Tenggara Timur \\ E-mail : febrianylado61@gmail.com, margiebolla@gmail.com
}

\begin{abstract}
ABSTRAK
Taksi GOGO adalah taksi pertama yang dilengkapi argometer di Kota Kupang dengan jumlah armada 43 unit. Tujuan penelitian ini adalah untuk mengetahui karateristik pengguna Taksi, pengaruh permintaan Taksi GOGO dibandingkan dengan angkutan umum yang lain, kebutuhan Taksi GOGO di Kota Kupang. Berdasarkan data dari 100 responden, diketahui karateristik pengguna Taksi di Kota Kupang sebagian besar berumur 25-34 tahun, mempunyai 1 kendaraan pribadi, mempunyai penghasilan diatas Rp.3.000.000, dan menggunakan Taksi GOGO sekali seminggu. Kebutuhan Taksi GOGO adalah sebanyak 91 armada, maka perlu ditambah 48 unit. Hasil untuk model logit binomial selisih $83 \%$ orang memilih menggunakan Taksi GOGO meskipun dengan biaya yang sama dengan angkutan umum lainnya dan $78 \%$ orang memilih menggunakan Taksi GOGO meskipun dengan waktu tempuh yang sama. Untuk model logit binomial nisbah $68 \%$ orang memilih Taksi GOGO meskipun dengan biaya yang sama dengan angkutan umum lainnya dan $69 \%$ dan orang memilih Taksi GOGO meskipun dengan waktu tempuh yang sama.
\end{abstract}

Kata kunci : Kebutuhan Taksi, Taksi, Stated Preference.

\section{PENDAHULUAN}

Kota Kupang sebagai Ibukota Propinsi Nusa Tenggara Timur merupakan kota dengan pergerakan transportasi yang semakin padat. Posisinya yang strategis memungkinkan Kota Kupang kedepan akan menjadi pilihan terbaik sebagai pintu gerbang masuk/keluar orang, perdagangan arus barang/jasa, pada arus lokal, regional, nasional. Kebutuhan yang semakin meningkat ini kemudian menuntut adanya layanan transportasi yang semakin baik. Salah satu layanan transportasi darat yang ada adalah angkutan umum.

Pada daerah perkotaan, salah satu moda angkutan umum yang umum digunakan adalah taksi. Taksi merupakan angkutan dengan menggunakan mobil penumpang umum yang diberi tanda khusus dan dilengkapi dengan argometer yang melayani angkutan dari pintu ke pintu dalam wilayah operasi terbatas. Dengan kata lain, dari sisi keleluasaan dalam hal waktu, rute pelayanan, dan tempat pemberhentian, taksi lebih memberikan kemudahan yang menjadi kelebihan utamanya dibandingkan dengan angkutan umum yang lain.

Saat ini telah beroperasi suatu angkutan umum taksi yang baru di Kota Kupang yaitu Taksi GOGO. Taksi GOGO beroperasi pada tanggal 2 Maret 2016 (Pos Kupang, Senin 7 Maret 2016) dengan jumlah armada saat ini sebanyak 43 unit. Taksi GOGO ini merupakan angkutan umum taksi pertama dan satusatunya di Kota Kupang saat ini yang sistem perhitungan tarifnya menggunakan argometer. Perhitungan tarif dengan sistem argometer ini menjadi hal yang baru bagi masyarakat di Kota Kupang.

Pertimbangan seseorang untuk mengambil keputusan memilih moda transportasi dalam melakukan perjalanan dipengaruhi oleh banyak faktor baik itu dari segi kenyamanan pelayanan yang diberikan oleh penyedia jasa, keterjangkauan tarif ataupun faktor lainnya. Dengan beroperasinya Taksi GOGO ini maka bertambahlah pilihan moda angkutan umum di Kota Kupang. Oleh karena itu, maka perlu dilakukan analisis terhadap beberapa faktor yang diduga mempengaruhi masyarakat Kota Kupang dalam mengambil keputusan untuk memilih menggunakan jasa Taksi GOGO dibandingkan dengan angkutan umum lainnya. Karena merupakan jenis angkutan umum yang baru maka perlu dicari tahu pula apakah dengan jumlah armada Taksi 
GOGO yang tersedia saat ini sudah sesuai dengan kebutuhan masyarakat di Kota Kupang.

\section{TINJAUAN PUSTAKA}

\section{Transpotasi Angkutan Umum}

Angkutan adalah pemindahan orang dan/atau barang dari satu tempat ke tempat lain dengan menggunakan kendaraan, sedangkan kendaran umumladalah setiap kendaraan bermotor yang disediakan untuk dipergunakan oleh umum dengan dipungut biaya baik langsung maupun tidak langsung Peran angkutan umum sangat penting dalam sistem kota karena tidak semua masyarakat mampu untuk membeli kendaraan pribadi (Afianto, 2004).

\section{Taksi}

Taksi merupakan sebuah transportasi nonpribadi yang umumnya adalah sedan (Wikipedia). Wilayah operasi angkutan taksi menurut Keputusan Menteri Perhubungan No.35 Tahun 2003 harus ditetapkan dengan mempertimbangkan beberapa hal yaitu, kebutuhan jasa angkutan taksi, perkembangan daerah kota atau perkotaan dan tersedianya prasarana jalan yang memadai.

\section{Teknik Stated Preference}

Teknik Stated Preference (SP) mendasarkan pada konsep ekonomi klasik yaitu utilitas penggunaan suatu prodak. Utilitas mempresentasikan suatu kepuasan akan keuntungan seseorang ketika mengeluarkan biaya untuk memperoleh suatu produk. Pemakai jasa diasumsikan akan memilih jasa yang memberikan utilitas maksimal bagi dirinya.

\section{Analisis Model Logit Binomial}

\section{a. Analisis Model Logit Binomial Selisih}

Model logit-binomial-selisih adalah probabilitas bahwa individu memilih angkutan umum adalah fungsi selisih utilitas antara kedua moda. Dengan menganggap bahwa fungsi utilitas linier, maka perbedaan utilitas dapat diekspresikan dalam bentuk perbedaan dalam sejumlah $\mathrm{n}$ atribut yang relevan diantara kedua moda. Nilai probabilitas kedua moda yang ditinjau dapat ditulis dalam bentuk persamaan berikut (Tamin, 2000):

$$
P_{1}=\frac{1}{1+\exp ^{-\left(\alpha+\beta\left(C_{\left.\left.1-C_{2}\right)\right)}\right.\right.}}
$$

Dimana:

$$
\begin{aligned}
& \mathrm{P}_{1}=\begin{array}{l}
\text { Probabilitas perjalanan menggunakan } \\
\text { moda angkutan } 1
\end{array} \\
& \mathrm{C}_{1}=\text { Pemisalan pilihan moda transportasi } 1
\end{aligned}
$$

$\mathrm{C}_{2}$ =Pemisalan terhadap pilihan moda transportasi 2

b. Analisis Model Logit Binomial Nisbah

Persamaan umum model binomial logit nisbah menurut Tamin (2000) adalah sebagai berikut:

$$
P_{1}=\frac{1}{1+\alpha\left(\frac{C_{1}}{C_{2}}\right)^{\beta}}
$$

Dimana,

$\mathrm{P}_{1}=$ Probabilitas perjalanan menggunakan moda angkutan 1

$\mathrm{C}_{1}=$ Pemisalan terhadap pilihan moda transportasi 1

$\mathrm{C}_{2}=$ Pemisalan terhadap pilihan moda transportasi 2

Persamaan diatas dapat dijabarkan lebih lanjut menjadi persamaan sebagai berikut:

Dimana,

$$
\log \left(\frac{1-P_{1}}{P_{1}}\right)=\log \alpha+\beta \log \frac{C_{1}}{C_{2}}
$$

$\mathrm{P}_{1}=$ Probabilitas perjalanan menggunakan moda angkutan 1

$\mathrm{C}_{1}=$ Pemisalan terhadap pilihan moda transportasi 1

$\mathrm{C}_{2}$ =Pemisalan terhadap pilihan moda transportasi 2

Kita mempunyai data $P_{1}, C_{1}$ dan $C_{2}$ sehingga parameter yang tidak diketahui adalah nilai $\alpha$ dan $\beta$. Nilai ini dapat dikalibrasi dengan analisis regresi linear dengan sisi kiri persamaan berperan sebagai peubah tidak bebas dan $\log \frac{C_{1}}{C_{2}}$ sebagai peubah bebas sehingga $\beta$ adalah kemiringan garis regresi dan $\log \alpha$ adalah intersepnya (Tamin, 2000).

Dengan asumsi $Y_{i}=\left(\frac{1-P_{1}}{P_{1}}\right)$ dan $X_{i}=$ $\log \frac{C_{1}}{C_{2}}$ sehingga persamaan tidak linear diatas dapat diubah menjadi persamaan linear yang bentuknya berubah menjadi seperti berikut:

$$
Y=A+B X
$$

\section{Analisis Kebutuhan Taksi Saat Ini}

a. Multiple Classification Analysis (MCA) Penelitian ini menggunakan pendekatan analisis kategori untuk mengetahui bangkitan pergerakan. Pendekatan yang digunakan adalah dengan metode bangkitan pergerakan Analisis Kategori- Orang, sedang untuk pemodelan dilakukan dengan pemodelan metode Multiple Classification Analysis (Afianto, 2004). Variabel tak bebas untuk model yang dikembangkan adalah besarnya bangkitan pergerakan per satuan waktu tertentu. Dalam hal ini satuan waktu yang digunakan adalah minggu. Jadi tingkat pergerakan/variabel tak bebas dalam satuan 
perjalanan/minggu. Kandidat variabel bebas untuk model yang akan dikembangkan dipilih dari data sosial-ekonomi dari pengguna jasa taksi. Dari pengamatan terhadap data yang dikumpulkan bahwa tingkat pergerakan taksi sangat dipengaruhi oleh penghasilan keluarga per-bulan, kepemilikan kendaraan pribadi dan ukuran keluarga.

Kandidat variabel bebas yang digunakan dalam pemodelan metode Multiple Classification Analysis adalah sebagai berikut:

a. Model 1

URT (ukuran rumah tangga) dan KK (kepemilikan kendaraan).

\section{b. Model 2}

URT (ukuran rumah tangga) dan pendapatan.

Variabel bebas yang ada dalam model-model yang akan dianalisis sebanyak 2 variabel bebas pada setiap model, maka analisa yang dipakai adalah Two Way Anova. Dari hasil perhitungan Metode Multiple Classification Analysis dengan menggunakan bantuan software Statistical Product and Service Solution (SPSS), jika didapati sel kosong pada setiap model maka model yang paling baik digunakan untuk perhitungan adalah model yang mempunyai sel kosong paling sedikit. Sel-sel kosong ini berarti bahwa tidak ada responden yang termasuk dalam kategori tersebut.

\section{Statistical Product and Service Solution (SPSS)}

SPSS merupakan software pengolah data statistik. Kelebihan dari software ini adalah didukung oleh Online Analytical Processing (OLAP) yang memudahkan pengolahan data dan akses data dari berbagai software lain.

\section{METODE PENELITIAN}

\section{Lokasi, Waktu dan Objek Penelitian}

Penelitian ini dilakukan di Kota Kupang, Propinsi Nusa Tenggara Timur yang merupakan lingkup wilayah operasi Taksi GOGO. Waktu penelitian dilakukan pada bulan Maret 2016 sampai dengan Juni 2017. Objek penelitian ini adalah angkutan umum Taksi GOGO yang beroperasi di Kota Kupang.

\section{Sumber Data}

Data primer dalam penelitian ini adalah data karateristik responden dan pilihan responden dari alternatif pilihan yang ada yang diperoleh dari kuisoner. Data sekunder dalam penelitian ini diperoleh dari dari instansi terkait atau literatur yang berkaitan dengan topik penelitian, meliputi data penduduk Kota Kupang dan data Perusahaan Taksi GOGO.

Teknik Pengambilan Data dan Teknik

\section{Analisa Data}

Teknik pengumpulan data yang digunakan adalah teknik kuisoner dan teknik pengumpulan data. Langkah-langkah yang dilakukan dalam teknik analisa data:

1. Melakukan pengumpulan data-data primer dan sekunder yang berupa data teknis dan data penunjang lainnya yang digunakan dalam analisa.

2. Mengolah data-data yang telah diketahui khususnya data dari kuisoner.

3. Manganalisis karateristik pengguna Taksi di Kota Kupang.

4. Menganalisis data Stated Preference dengan menggunakan perbandingan antara model logit binomial selisih dan logit binomial nisbah.

\section{HASIL DAN PEMBAHASAN}

\section{Hasil Analisis Karateristik Pengguna Taksi di Kota Kupang}

1. Berdasarkan golongan umur 16-59 tahun dan jumlah sampel 100 orang, pengguna taksi dengan umur 15-24 tahun sebanyak $37 \%$, umur 25-34 tahun sebanyak $48 \%$, umur 35-44 tahun sebanyak $10 \%$, umur 45-54 tahun sebanyak 5\%, sedangkan untuk umur diatas 55 tahun sebanyak $0 \%$. Dari hasil data ini terlihat bahwa pengguna jasa Taksi GOGO ini lebih banyak yang berumur 15-34 tahun.

2. Pengguna Taksi GOGO yang tidak mempunyai kendaraan pribadi sebanyak $20 \%$, yang mempunyai 1 kendaraan pribadi sebanyak $67 \%$, yang mempunyai 2 kendaraan pribadi sebanyak $11 \%$ dan yang mempunyai lebih dari 2 kendaraan bermotor sebanyak $2 \%$.

3. Berdasarkan penghasilan per bulan, pengguna Taksi GOGO yang mempunyai penghasilan kurang dari Rp.1.000.000 sebanyak 23\%, penghasilan Rp.1.000.000 sampai Rp.1.500.000 sebanyak $17 \%$, penghasilan Rp.1.500.000 sampai Rp.3.000.000 sebanyak $25 \%$ dan yang mempunyai penghasilan lebih dari Rp.3.000.000 sebanyak $35 \%$.

4. Hasil survei menunjukkan bahwa yang menggunakan Taksi GOGO seminggu sekali sebanyak $41 \%$, 2 kali seminggu sebanyak $33 \%$, lebih dari 2 kali seminggu sebanyak $16 \%$ sedangkan lain-lain sebanyak $10 \%$.

\section{Hasil Analisis Data Stated Preference}

1. Model Logit Binomial Selisih Pengaruh Biaya

Tabel hasil perhitungan untuk model binomial selisih pengaruh biaya dapat 
dilihat pada lampiran 1. Dari hasil tabel perhitungan di atas diperoleh $\alpha=-0.771$ dan $\beta=-0.044$, maka dengan persamaan 1 , didapat persamaan logit-binomialselisih sebagai berikut:

$P=\frac{1}{1+e^{-\left(0.7711+0.044\left(\mathrm{C}_{\mathrm{Taksi}}-\mathrm{C}_{\mathrm{AU}}\right)\right.}}$

Apabila model persamaan tersebut dimasukkan ke dalam grafik, maka akan didapat grafik pada Lampiran 2.

2. Model Logit Binomial Selisih Pengaruh Waktu

Tabel hasil perhitungan untuk model binomial selisih pengaruh waktu dapat dilihat pada lampiran 3 .

Dari hasil tabel perhitungan di atas diperoleh $\alpha=-0.756$ dan $\beta=-0.021$, maka dengan persamaan 2.1, didapat persamaan logit-binomial-selisih sebagai berikut:

$P=\frac{1}{1+e^{-\left(0.756+0.021\left(\mathrm{C}_{\mathrm{Taksi}}-\mathrm{C}_{\mathrm{AU}}\right)\right.}}$

Apabila model persamaan tersebut dimasukkan ke dalam grafik, maka akan didapat grafik pada lampiran 4.

3. Model Logit Binomial Nisbah Pengaruh Biaya

Tabel hasil perhitungan untuk model binomial nisbah pengaruh biaya dapat dilihat pada lampiran 5 .

Dari hasil tabel perhitungan di atas diperoleh $\alpha=0.473$ dan $\beta=1.584$, maka didapat persamaan logit-binomial-nisbah sebagai berikut:

$P=\frac{1}{1+0.473 \cdot\left(\frac{C_{T a k s i}}{C_{A U}}\right)^{1.584}}$

Apabila model persamaan tersebut dimasukkan ke dalam grafik, maka akan didapat grafik pada lampiran 6 .

4. Model Logit Binomial Nisbah Pengaruh Biaya

Tabel hasil perhitungan untuk model binomial nisbah pengaruh biaya dapat dilihat pada lampiran 7

Dari hasil tabel perhitungan di atas diperoleh $\alpha=0.469$ dan $\beta=0.250$, maka didapat persamaan logit-binomial-nisbah sebagai berikut:

$P=\frac{1}{1+0.469 \cdot\left(\frac{C_{T a k s i}}{C_{A U}}\right)^{0.250}}$

Apabila model persamaan tersebut dimasukkan ke dalam grafik, maka akan didapat grafik pada Lampiran 8.
Berdasarkan persamaan 4 maka persamaan linear untuk model logit-binomial-selisih, dapat dituliskan sebagai berikut:
a. Pengaruh biaya
$Y_{i}=-0.771-0.044 X_{i}$
b. Pengaruh waktu
$Y_{i}=-0.756-0.021 X_{i}$

Berdasarkan persamaan 4 maka persamaan linear untuk model logit-binomial-nisbah, dapat dituliskan sebagai berikut:

a. Pengaruh biaya

$$
Y_{i}=-0.325+1.584 X_{i}
$$

b. Pengaruh waktu

$$
Y_{i}=-0.328+0.250 X_{i}
$$

\section{Hasil Analisis Data Stated Preference}

1. Multiple Classification Analysis (MCA)

Tabel 1. Tingkat Pergerakan Model 1 metode

\begin{tabular}{|c|c|c|c|c|c|}
\hline \multirow{2}{*}{$\begin{array}{l}\text { Kepemilikan } \\
\text { Kendaraan }\end{array}$} & \multicolumn{5}{|c|}{ Ukuran Keluarga } \\
\hline & 1 & 2 & 3 & 4 & $>4$ \\
\hline 0 & & 3,50 & 2,00 & 2,00 & 2,45 \\
\hline 1 & & 2,33 & 1,77 & 2,00 & 1,79 \\
\hline 2 & & 2,00 & 2,00 & 3,00 & 1,67 \\
\hline$<2$ & & & & 3,00 & 2,00 \\
\hline
\end{tabular}
MCA (Perjalanan/Minggu/Keluarga)

Tabel 2. Tingkat Pergerakan Model 2 metode

\begin{tabular}{|c|c|c|c|c|c|}
\hline Penghasilan & \multicolumn{5}{|c|}{ Ukuran Keluarga } \\
\hline $\begin{array}{c}\text { Keluarga per } \\
\text { Bulan (Rp) }\end{array}$ & 1 & 2 & 3 & 4 & $>4$ \\
\hline$<1$ juta & & 4,00 & & 2,29 & 2,07 \\
\hline $\begin{array}{c}1 \text { juta }-1,5 \\
\text { juta }\end{array}$ & & 4,00 & 2,40 & 2,00 & 2,10 \\
\hline $\begin{array}{c}1,5 \text { juta }-3 \\
\text { juta }\end{array}$ & & 2,75 & 1,71 & 2,14 & 1,71 \\
\hline$>3$ juta & & 1,33 & 1,50 & 2,00 & 1,80 \\
\hline
\end{tabular}
MCA (Perjalanan/Minggu/Keluarga)

Hasil perhitungan tingkat pergerakan pada lampiran 5 dan lampiran 6 terlihat bahwa terdapat 6 sel kosong pada tabel model 1 dan 5 sel kosong pada model 2 . sel-sel tersebut kosong karena tidak ada responden pada kriteria tersebut. Oleh karena itu model yang lebih baik tingkat bangkitan pergerakan taksi saat ini adalah model 2.

2. Jumlah Taksi GOGO yang Dibutuhkan Tabel perhitungan kebutuhan taksi saat ini 
terlampir pada Lampiran 9.

\section{Pembahasan}

Berdasarkan hasil analisis deskriptif pengguna Taksi yang dilakukan dari data kuisoner yang diberikan kepada 100 orang responden, maka diperoleh data sebagai berikut:

a. $37 \%$ berumur $15-24$ tahun, $48 \%$ berumur 25-34 tahun, $10 \%$ berumur $35-44$ tahun, $5 \%$ berumur $45-54$ tahun dan $0 \%$ berumur diatas 55 tahun. Dari data ini terlihat bahwa pengguna taksi lebih banyak pada rentan umur 25-34 tahun dan paling sedikit pada umur diatas 45 tahun.

b. $20 \%$ responden yang tidak mempunyai kendaraan pribadi, $67 \%$ responden mempunyai 1 kendaraan pribadi, $11 \%$ responden mempunyai 2 kendaraan pribadi dan $2 \%$ responden yang mempunyai kendaraan pribadi lebih dari 2 . Dari data ini terlihat bahwa pergerakan pengguna taksi didominasi oleh responden yang hanya memiliki 1 kendaraan pribadi dan respponden yang memiliki kendaraan pribadi lebih dari 2, tidak terlalu berminat untuk menggunakan taksi.

c. $23 \%$ responden mempunyai penghasilan kurang dari Rp.1.000.000, 17\% responden mempunyai penghasilan antara Rp.1.000.000 sampai Rp.1.500.000, 25\% responden mempunyai penghasilan antara Rp.1.500.000 sampai Rp.3.000.000, dan 35\% responden mempunyai penghasilan lebih dari Rp.3.000.000. Berdasarkan data tersebut, terlihat bahwa yang berpenghasilan diatas Rp.3.000.000 lebih banyak menggunakan taksi dibandingkan dengan yang berpenghasilan dibawah dari Rp.3.000.000.

d. $41 \%$ responden menggunakan Taksi GOGO seminggu sekali, 33\% responden 2 minggu sekali, $16 \%$ responden lebih dari 2 kali seminggu dan $10 \%$ responden tidak menentu menggunakan Taksi GOGO. Berdasarkan data tersebut, terlihat bahwa responden lebih banyak melakukan perjalanan menggunakan Taksi GOGO sebanyak sekali seminggu.

Berdasarkan analisis pemilihan moda antara penumpang Taksi GOGO dan angkutan umum lainnya menggunakan perbandingan antara model logit binomial selisih dan logit binomial nisbah dengan bantuan Microsoft Excel diperoleh hasil sebagai berikut:

a. Model logit binomial selisih

$83 \%$ orang akan memilih menggunakan Taksi GOGO, meskipun biaya Taksi GOGO sama dengan biaya angkutan umum lainnya dan $78 \%$ orang akan memilih menggunakan Taksi GOGO, meskipun waktu tempuh menggunakan Taksi GOGO sama dengan waktu tempuh menggunakan angkutan umum lainnya.

b. Model logit binomial nisbah

$68 \%$ orang akan memilih Taksi GOGO, meskipun biaya Taksi GOGO sama dengan biaya angkutan umum lainnya dan $69 \%$ orang akan memilih Taksi GOGO, meskipun waktuh tempuh menggunakan Taksi GOGO sama dengan waktu tempuh menggunakan angkutan umum lainnya.

Analisis kebutuhan Taksi GOGO saat ini diawali dengan mengembangkan 2 model variabel bebas yaitu model 1 adalah ukuran rumah tangga dan kepemilikan kendaraan, model 2 adalah ukuran rumah tangga dan pendapatan dengan variabel tak bebas adalah besarnya pergerakan Taksi per minggu untuk mendapatkan rata-rata tingkat pergerakan untuk setiap model. Dari hasil perhitungan masing-masing model dengan metode Multiple Classification Analysis (MCA) diketahui bahwa model 2 adalah model yang terbaik untuk dipakai dalam perhitungan selanjutnya.

Dari perhitungan Taksi GOGO saat ini dengan menggunakan data rata-rata tingkat pergerakan, presentase pengguna Taksi GOGO pada setiap kategori, pengguna Taksi di Kota Kupang, dan data permintaan Taksi GOGO per minggu maka didapat kebutuhan Taksi GOGO saat ini adalah 91 armada.

\section{KESIMPULAN DAN SARAN}

\section{Kesimpulan}

Dari hasil penelitian ini terlihat bahwa karateristik pengguna Taksi di Kota Kupang adalah berumur 15-24 tahun, $48 \%$ berumur $25-$ 34 tahun, $10 \%$ berumur $35-44$ tahun, $5 \%$ berumur $45-54$ tahun dan $0 \%$ berumur diatas 55 tahun. $20 \%$ responden yang tidak mempunyai kendaraan pribadi, $67 \%$ responden mempunyai 1 kendaraan pribadi, $11 \%$ responden mempunyai 2 kendaraan pribadi dan $2 \%$ responden yang mempunyai kendaraan pribadi lebih dari 2. $23 \%$ responden mempunyai penghasilan kurang dari Rp.1.000.000, $17 \%$ responden mempunyai penghasilan antara Rp.1.000.000 sampai Rp.1.500.000, 25\% responden mempunyai penghasilan antara Rp.1.500.000 sampai Rp.3.000.000, dan 35\% responden mempunyai penghasilan lebih dari Rp.3.000.000. 41\% responden menggunakan Taksi GOGO seminggu sekali, 33\% responden 2 minggu sekali, $16 \%$ responden lebih dari 2 kali seminggu dan $10 \%$ responden tidak menentu menggunakan Taksi GOGO. 
Berdasarkan analisis perbandingan antara model logit binomial selisih dan logit binomial nisbah diperoleh hasil untuk model logit binomial selisih $83 \%$ orang akan memilih menggunakan Taksi GOGO, meskipun biaya Taksi GOGO sama dengan biaya angkutan umum lainnya dan $78 \%$ orang akan memilih menggunakan Taksi GOGO, meskipun waktu tempuh menggunakan Taksi GOGO sama dengan waktu tempuh menggunakan angkutan umum lainnya. Dan untuk model logit binomial nisbah, $68 \%$ orang akan memilih Taksi GOGO, meskipun biaya Taksi GOGO sama dengan biaya angkutan umum lainnya dan $69 \%$ orang akan memilih Taksi GOGO, meskipun waktuh tempuh menggunakan Taksi GOGO sama dengan waktu tempuh menggunakan angkutan umum lainnya.

Berdasarkan data Stated Preference diketahui bahwa jumlah Taksi GOGO yang dibutuhkan saat ini adalah sebanyak 91 armada.

\section{DAFTAR PUSTAKA}

Afianto, M. Ardani. (2004). Analisis Elastisitas Tingkat Kebutuhan Taksi Kota Semarang Dengan Teknik Stated Preference. Semarang: Universitas Dipenogoro.

Taminm, O. Z. (2000). Perencanaan dan Permodelan Transportasi. Bandung: Jurusan Teknik Sipil ITB.

Wadu, Amy (2020). To Reduce Traffic Jams On Piet A. Tallo Street, Kupang City, UKaRsT 4 (2), $138-150$ 
Febriany S. L. Lado ${ }^{1 *}$ dan Margareth Bolla ${ }^{2}$

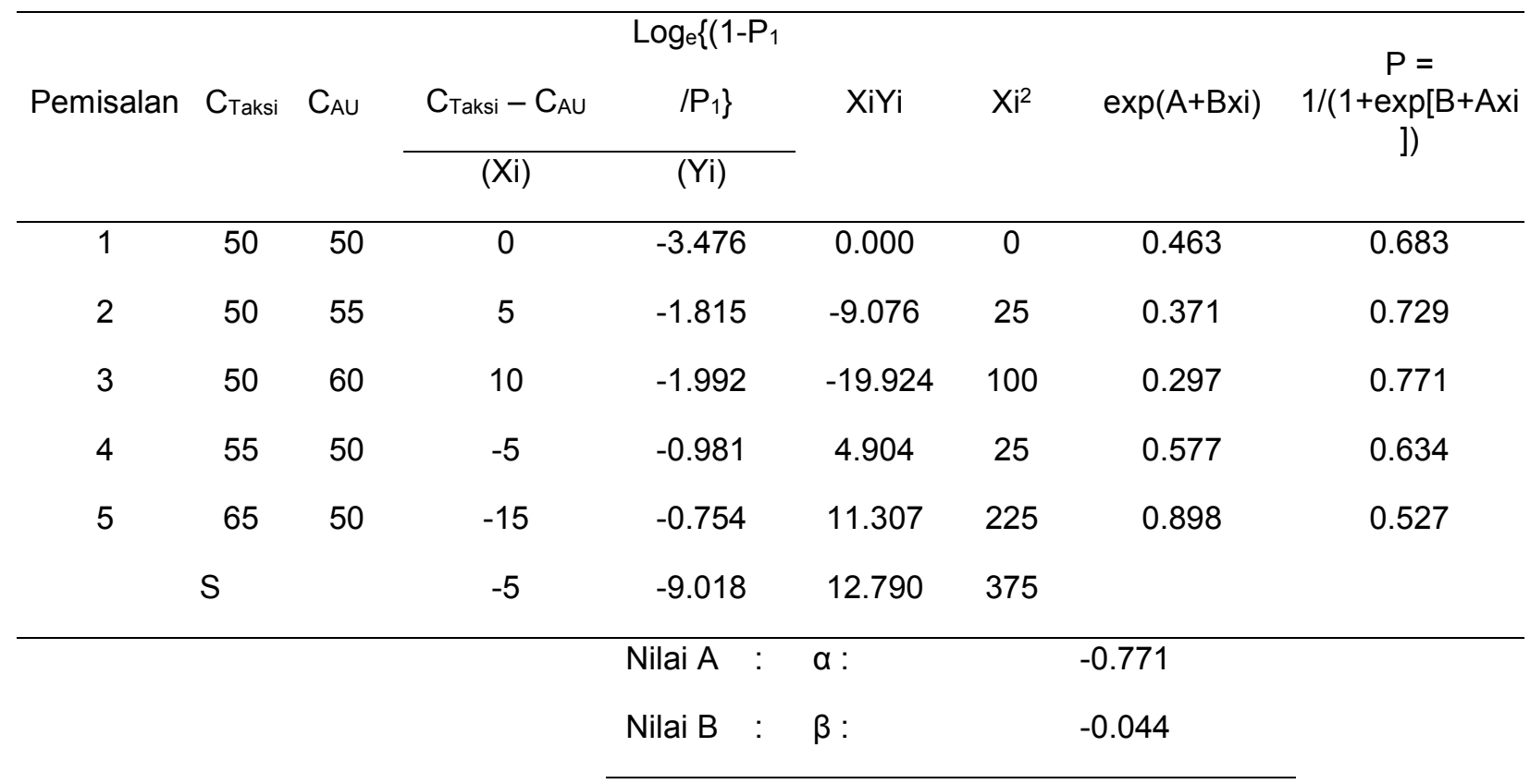

Lampiran 2. Gambar Grafik Model Binomial Selisih Pengaruh Biaya

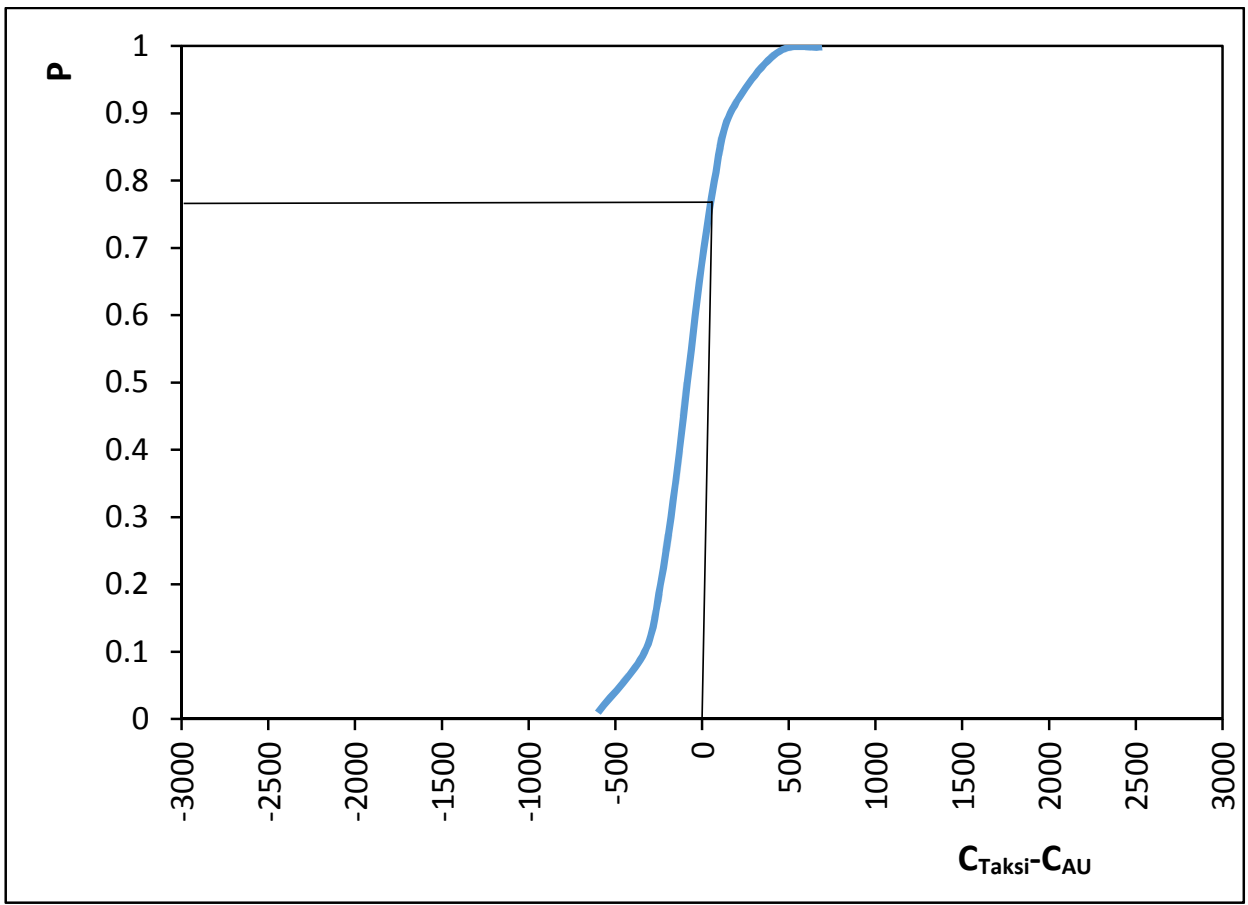

Lampiran 3. Tabel Perhitungan Untuk Model Binomial Selisih Pengaruh Waktu 


\begin{tabular}{|c|c|c|c|c|c|c|c|}
\hline $\mathrm{C}_{\text {Taksi }}$ & $\mathrm{C}_{\mathrm{AU}}$ & $\begin{array}{c}C_{\text {Taksi }}-\mathrm{C}_{\mathrm{AU}} \\
(\mathrm{Xi})\end{array}$ & $\begin{array}{c}\log _{e}\left\{\left(\mathrm{P}_{1} / 1-\mathrm{P}_{1}\right\}\right. \\
(\mathrm{Yi})\end{array}$ & XiYi & $\mathrm{Xi}^{2}$ & $\exp (A+B x i)$ & $P=1 /(1+\exp [B+A x i])$ \\
\hline 15 & 15 & 0 & -3.178 & 0.000 & 0 & 0.469 & 0.681 \\
\hline 15 & 30 & 15 & -2.442 & -36.635 & 225 & 0.342 & 0.745 \\
\hline 15 & 45 & 30 & -1.658 & -49.747 & 900 & 0.249 & 0.800 \\
\hline 30 & 15 & -15 & -0.994 & 14.929 & 225 & 0.644 & 0.608 \\
\hline \multirow[t]{4}{*}{45} & 15 & -30 & -0.800 & 24.004 & 900 & 0.884 & 0.531 \\
\hline & & 0 & -9.073 & -47.459 & 2250 & & \\
\hline & & & Nilai A & $\alpha:$ & & -0.756 & \\
\hline & & & Nilai B & $\beta:$ & & -0.021 & \\
\hline
\end{tabular}

Lampiran 4. Gambar Grafik Model Binomial Selisih Pengaruh Waktu

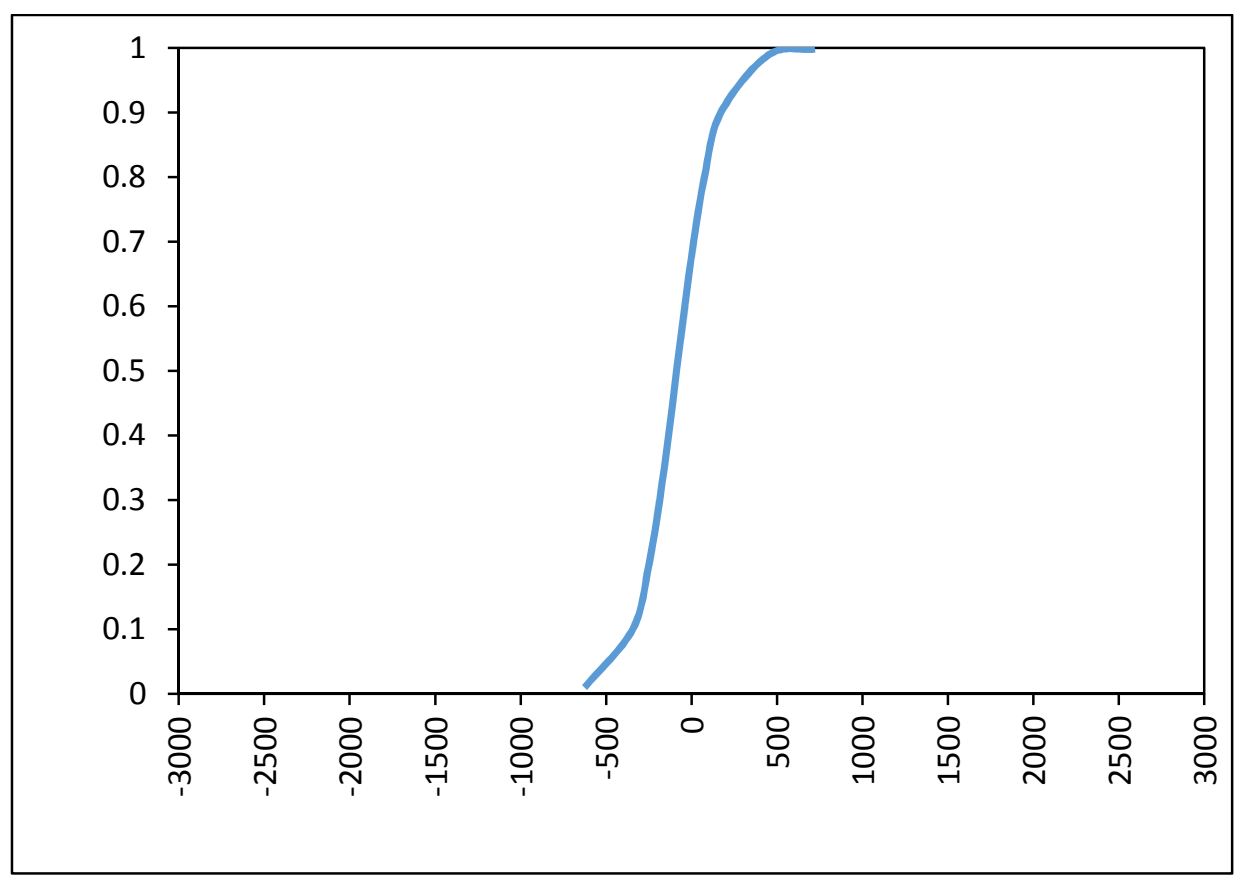

Lampiran 5. Tabel Perhitungan Untuk Model Binomial Nisbah Pengaruh Biaya 
Febriany S. L. Lado ${ }^{1 *}$ dan Margareth Bolla ${ }^{2}$

\begin{tabular}{|c|c|c|c|c|c|c|c|c|}
\hline \multirow[b]{2}{*}{$\mathrm{C}_{\text {Tasik }}$} & \multirow{2}{*}{$\mathrm{C}_{\mathrm{AU}}$} & $\mathrm{C}_{\text {Taksi }} / \mathrm{C}_{\mathrm{AL}}$ & $\log (\mathrm{Wi})$ & $\log \{(1-P) / P\}$ & \multirow{2}{*}{ XiYi } & \multirow[b]{2}{*}{$X i^{2}$} & \multirow[b]{2}{*}{$\mathrm{Wi}^{\beta}$} & \multirow{2}{*}{$P=1 /\left(1+\left(\alpha W i^{\beta}\right)\right)$} \\
\hline & & (Wi) & $(\mathrm{Xi})$ & $(\mathrm{Yi})$ & & & & \\
\hline 50 & 50 & 1.000 & 0.000 & -1.509 & 0.000 & 0.000 & 1.000 & 0.678 \\
\hline 50 & 55 & 0.909 & -0.095 & -0.788 & 0.075 & 0.009 & 0.859 & 0.710 \\
\hline 50 & 60 & 0.833 & -0.183 & -0.865 & 0.157 & 0.033 & 0.749 & 0.738 \\
\hline 55 & 50 & 1.100 & 0.095 & -0.410 & -0.039 & 0.009 & 1.163 & 0.645 \\
\hline 60 & 50 & 1.200 & 0.182 & -0.327 & -0.059 & 0.033 & 1.334 & 0.612 \\
\hline & $\Sigma$ & & 0.000 & -3.900 & 0.134 & 0.084 & & \\
\hline \multicolumn{7}{|c|}{$\mathrm{B}=\left(\mathrm{N} . \Sigma \mathrm{XiYi}-\left(\sum \mathrm{xi} . \Sigma \mathrm{yi}\right)\right) /\left(\mathrm{N} . \Sigma \mathrm{Xi2}-\left(\sum \mathrm{xi}\right) 2\right)$} & $\beta$ & 1.584 \\
\hline \multicolumn{8}{|c|}{$A=($ rata-rata $Y)-B($ rata-rata $X)$} & -0.325 \\
\hline & & & & & & & $\alpha$ & 0.473 \\
\hline
\end{tabular}

Lampiran 6. Gambar Grafik Model Binomial Nisbah Pengaruh Biaya

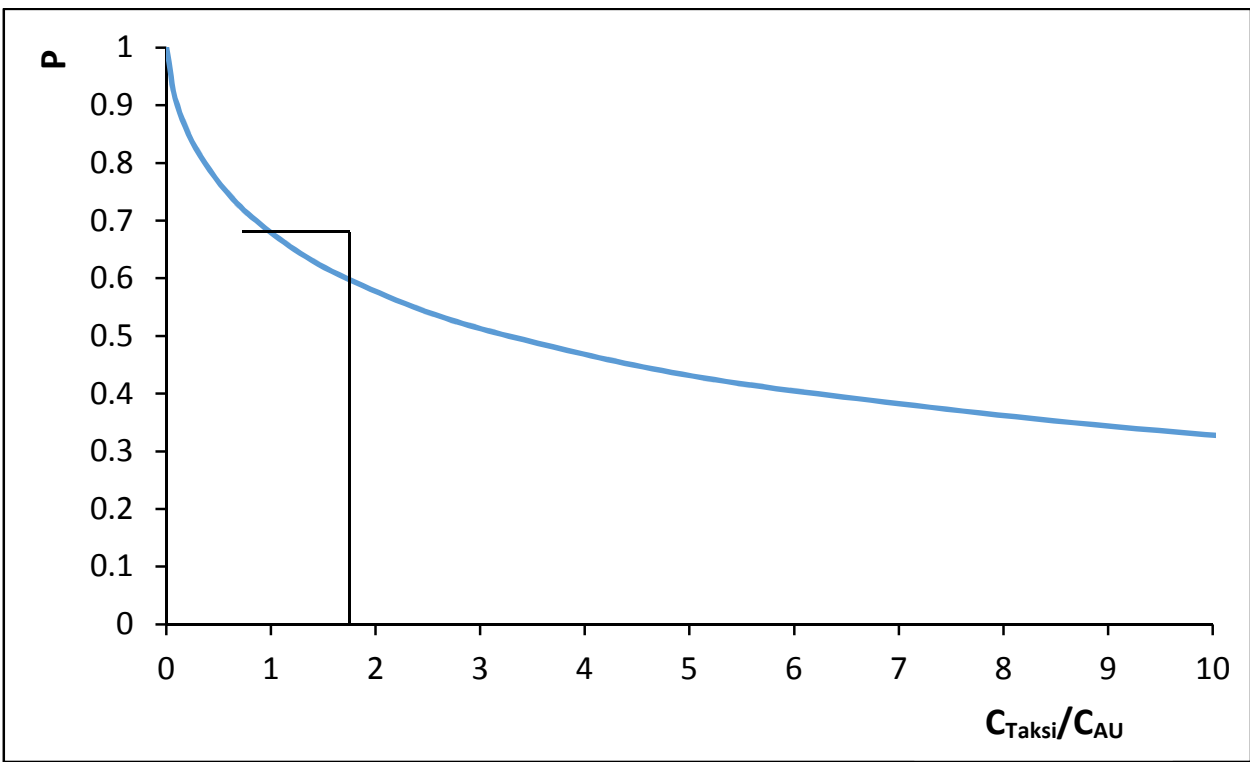

Lampiran 7. Tabel Perhitungan Untuk Model Binomial Nisbah Pengaruh Waktu 


\begin{tabular}{|c|c|c|c|c|c|c|c|c|}
\hline \multirow{2}{*}{$\mathrm{C}_{\text {Taksi }}$} & \multirow{2}{*}{$\mathrm{C}_{\mathrm{AU}}$} & $\mathrm{C}_{\text {Taksi }} / \mathrm{C}_{\mathrm{AU}}$ & $\log (\mathrm{Wi})$ & $\log \{(1-\mathrm{P}) / \mathrm{P}\}$ & \multirow{2}{*}{ XiYi } & \multirow{2}{*}{$\mathrm{Xi}^{2}$} & \multirow{2}{*}{$\mathrm{Wi}^{\beta}$} & \multirow{2}{*}{$P=1 /\left(1+\left(\alpha W_{i}^{\beta}\right)\right)$} \\
\hline & & (Wi) & $(\mathrm{Xi})$ & $(\mathrm{Yi})$ & & & & \\
\hline 15 & 15 & 1.000 & 0.000 & -1.380 & 0.000 & 0.000 & 1.000 & 0.681 \\
\hline 15 & 30 & 0.500 & -0.693 & -1.061 & 0.735 & 0.480 & 0.841 & 0.717 \\
\hline 15 & 45 & 0.333 & -1.099 & -0.720 & 0.791 & 1.207 & 0.759 & 0.737 \\
\hline 30 & 15 & 2.000 & 0.693 & -0.432 & -0.299 & 0.480 & 1.190 & 0.642 \\
\hline \multirow[t]{2}{*}{45} & 15 & 3.000 & 1.099 & -0.347 & -0.382 & 1.207 & 1.317 & 0.618 \\
\hline & \multirow[t]{2}{*}{$\Sigma$} & & 0.000 & -3.941 & 0.845 & 3.375 & & \\
\hline \multicolumn{6}{|c|}{$\mathrm{B}=\left(\mathrm{N} . \Sigma \mathrm{XiYi}-\left(\sum \mathrm{xi} . \Sigma \mathrm{yi}\right)\right) /\left(\mathrm{N} . \Sigma \mathrm{Xi} 2-\left(\sum \mathrm{xi}\right) 2\right)$} & & $\beta$ & 0.250 \\
\hline \multicolumn{8}{|c|}{$\mathrm{A}=($ rata-rata $\mathrm{Y})-\mathrm{B}($ rata-rata $\mathrm{X})$} & -0.328 \\
\hline & & & & & & & $\alpha$ & 0.469 \\
\hline
\end{tabular}

Lampiran 8. Gambar Grafik Model Binomial Nisbah Pengaruh Waktu

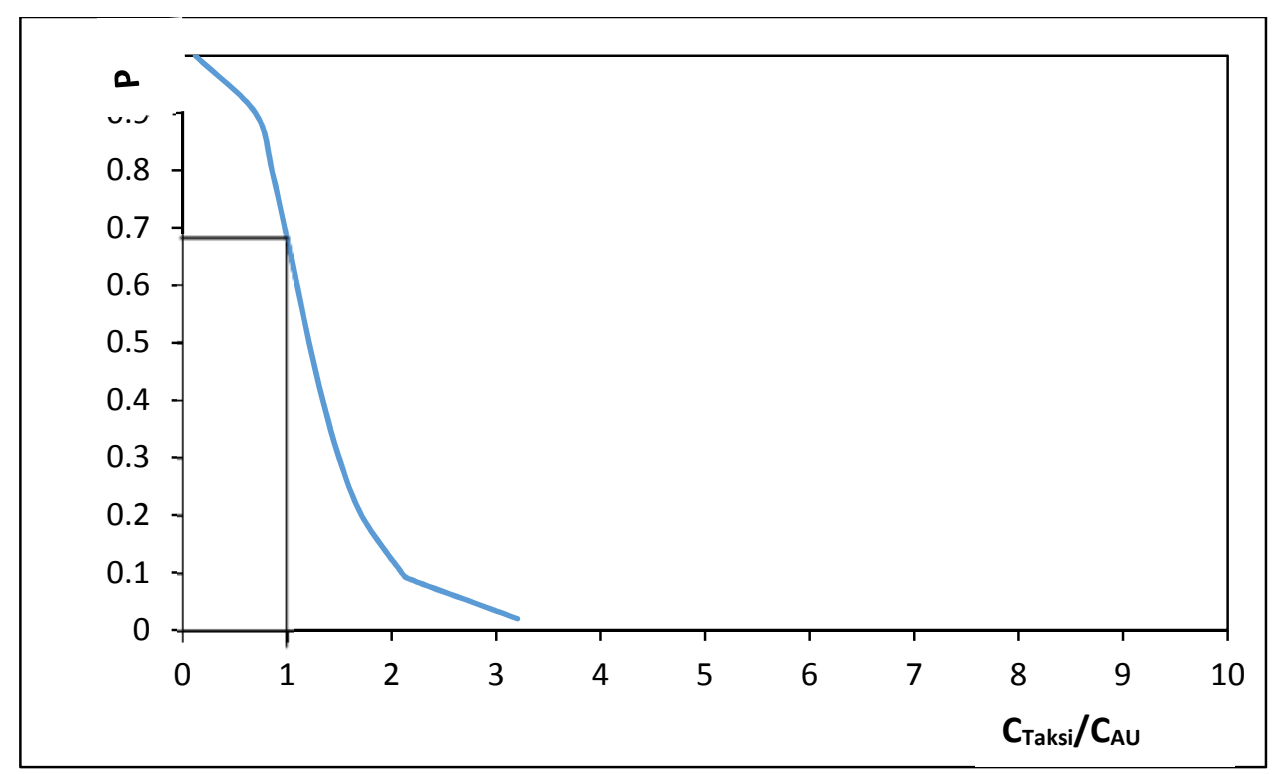


\begin{tabular}{l|l} 
Analisis Kebutuhan Taksi GOGO DI Kota Kupang Dengan Teknik Stated Preference & 89
\end{tabular} Febriany S. L. Lado ${ }^{1 *}$ dan Margareth Bolla ${ }^{2}$

Kategori Jumlah Perjalanan per hari

\begin{tabular}{|c|c|c|c|c|}
\hline $\begin{array}{c}\text { Ukuran Rumah } \\
\text { Tangga }\end{array}$ & $\begin{array}{c}\text { Penghasilan } \\
\text { Keluarga } \\
\text { per bulan (Rp) }\end{array}$ & $\begin{array}{c}\text { Presentase } \\
\text { Pengguna Taksi } \\
\text { (\%) }\end{array}$ & $\begin{array}{c}\text { Tingkat } \\
\text { Pergerakan }\end{array}$ & $\begin{array}{c}\begin{array}{c}\text { Pengguna Taksi } \\
\text { di Kupang } \\
=0,3 \%\end{array}\end{array}$ \\
\hline & $<1$ juta & 1 & 4,00 & 63 \\
\hline & 1 juta - 1,5 juta & 1 & 4,00 & 63 \\
\hline & 1,5 juta -3 juta & 4 & 2,75 & 174 \\
\hline & $>3$ juta & 3 & 1,33 & 63 \\
\hline & $<1$ juta & & & \\
\hline & 1 juta $-1,5$ juta & 5 & 2,40 & 190 \\
\hline 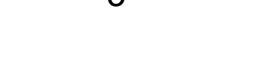 & 1,5 juta -3 juta & 7 & 1,71 & 190 \\
\hline & $>3$ juta & 6 & 1,50 & 143 \\
\hline & $<1$ juta & 7 & 2,29 & 254 \\
\hline 1 & 1 juta - 1,5 juta & 1 & 2,00 & 32 \\
\hline & 1,5 juta -3 juta & 7 & 2,14 & 237 \\
\hline & $>3$ juta & 6 & 2,00 & 190 \\
\hline & $<1$ juta & 7 & 2,07 & 492 \\
\hline & 1 juta - 1,5 juta & 1 & 2,10 & 333 \\
\hline & 1,5 juta -3 juta & 7 & 1,71 & 163 \\
\hline & $>3$ juta & 6 & 1,80 & 599 \\
\hline \multicolumn{4}{|c|}{ Total perjalanan } & 3186 \\
\hline \multicolumn{4}{|c|}{ Jumlah taksi yang dibutuhkan } & 91 \\
\hline
\end{tabular}

